\title{
Student Approaches to Learning Among University Students
}

\author{
Hee Chong Teoh ${ }^{1, *}$, Teng Teng Yap ${ }^{2}$ \\ ${ }^{1}$ Faculty of Educational Studies, University Putra Malaysia, Selangor, Malaysia \\ ${ }^{2}$ Faculty of Social Science, Arts and Humanities, Tunku Abdul Rahman University College, Kuala Lumpur, Malaysia
}

Email address:

hcteoh2008@hotmail.com (H. C. Teoh), yaptteng@yahoo.com (T. T. Yap)

\section{To cite this article:}

Hee Chong Teoh, Teng Teng Yap. Student Approaches to Learning Among University Students. American Journal of Applied Psychology. Special Issue: Psychology of University Students. Vol. 4, No. 3-1, 2015, pp. 15-20. doi: 10.11648/j.ajap.s.2015040301.13

\begin{abstract}
This study evaluated the learning characteristics of university students based on three learning approaches (surface approach, deep approach and achieving approach) and six subscales, namely three learning motives (LM) and three learning strategies (LS). A survey form adapted from Biggs's study process questionnaire (SPQ) was distributed to a total of 193 students at a private university college in Malaysia. This study employed descriptive correlation research design to address the research questions. Results of the study indicated that students were more prone to apply deep approach. Further analysis revealed a combination of "achieving strategy and deep motive" was the most popular approach among students. The pattern of surface and achieving approaches showed significant differences across subject variable. Proposed teaching methods were introduced to suit the needs of these major learning characteristics among university students.
\end{abstract}

Keywords: Approaches to Learning, Learning Motives, learning Strategies, Disciplines

\section{Introduction}

Student Approaches to Learning (SAL) can be defined as how learners process and handle the information or experience obtained. Different individual uses a different approach to interpret and analyze the information in order to absorb them to become part of learner's knowledge. The issue of SAL is important due to its close relationship with academic achievement of students [1-4].

According to Marton and Saljo [5], there are two different ways of learning called "surface" and "deep" approach. Students who adopted surface approach focused on rote learning or memorization of facts because they just aim to achieve a minimum requirement. In contrast, deep learners will study the content precisely in details and strive for complete comprehension of the meaning [6]. There is another approach to learning that was developed at a much later time, namely "achieving" [7, 8] or "strategic" approach [9]. Achieving/strategic approach learners will try to excel in their study by knowing the assessment requirements and criteria. They will prepare and try to fulfill whatever their teacher wants [8]. These three SALs will be the main discussion pertaining to the learning process of university students in the current study.
Previous studies have revealed that a surface approach to learning is related to poor quality processes and outcomes [1, $2,3,10]$. On the contrary, a deep approach to learning is related to high-quality processes and outcomes [4]. The achieving approach also tends to do well in the exam, but more externally driven to garner high grade in examination [8].

Although the previous findings supported the importance of SAL in learning processes, many Asian or South East Asian students still prefer to apply surface approach rather than deep approach in their study. Asian learners relied very much on a syllabus and textbooks, more teacher-directed and less self-directed in classroom discussion [11- 14]. In Malaysia, Fung [15] described Malaysian secondary and undergraduate students as surface rote learners and unfamiliar with deep approaches to learning. Their aim of the study was merely to pass examinations and to get a good job after graduation. Thang [16] also revealed that a majority of students from public and private universities in Malaysia were lack of personal autonomy and they preferred a teacher-centred approach to learning. Ziguras [13] quoting lecturers feedbacks indicated that Malaysian students are 
expecting to be spoon-fed, scared of saying the wrong things, wanting more direction, supervision and greater attention from lecturers. Pauline Goh [17] who conducted the study of SAL in Malaysian private higher education institution revealed the same findings. However, she explained that most of the surface learners were not satisfied with their SAL as it undermined the quality of their learning outcomes.

$\mathrm{Be}$ that as it may, there were previous studies revealed the other way round. Ling et al. [18] while comparing approaches to learning between Australian and Malaysian undergraduates in private educational institutions found that there was no significant difference in deep approach. Students in Malaysian score slightly higher in surface approach but the magnitude was slight. Thang [19] in her research conducted on distance learners and on-campus learners at one of the public universities in Malaysia also revealed the score on deep approach was higher irrespective of learning modes. Recently, some studies in Malaysian public higher institutions also found that undergraduates were more likely to apply deep approach or achieving approach rather than surface approach [10, 20, 21].

For this reason, the present study will further examine the phenomenon of SAL in Malaysian private higher institutions and deepen the understanding of this learning characteristic among students in a private university college. The combination of three learning motives (LM), namely surface motive, deep motive and achieving motive and three learning strategies (LS), namely surface strategy, deep strategy and achieving strategy will be taken into consideration in order to provide more information regarding SAL of the respondents. By recognizing the learning characteristics of students, researchers hope that it will help students and teachers to identify their weaknesses and finding solutions for the difficulties faced during learning or teaching processes.

In order to achieve the research objective as mentioned above, researchers have set the following research questions to guide the next discussion.

1. What are the approaches to learning adopted by the students at private university college?

2. What are the approaches to learning adopted by the students at private university college based on learning motive (LM) and learning strategy (LS)?

3. Does a discipline have an impact on the approaches to learning employed by students at private university college?

\section{Methodology}

This study employed a descriptive-correlation research design with a questionnaire survey. A total of 193 students (Social Science students $=116$, and Applied Sciences students $=77$ ) were selected from a private university college, to participate in this study. Students were asked to complete the questionnaire distributed to them. In order to secure responses, the questionnaire was administered during class session, and the return rate was $100 \%$.

In this study, the existing Study Process Questionnaire
(SPQ) designed by Biggs [7] was adapted and used to collect the research data from respondents. The modified SPQ contains 27 items divided among the three approaches to learning (deep, surface and achieving) into six motive and strategy scales. Each response to an item is to be answered on a four points Likert scale that describes the match with the respondent's behaviour: $1=$ strongly disagree; $2=$ disagree; $3=$ agree, and $4=$ strongly agree.

As to tailor the SPQ into Malaysian learner context, researchers considered the SPQ [7], R-SPQ-2F [22] and R-SPQ-2FM [23] in order to modify the subscales which better suit the comprehension of local students. For instance, the original item of "I find that at times studying gives me a feeling of deep personal satisfaction" modified to "sometimes, I am deeply satisfied with my study experience" and "I only study seriously what's given out in class lecture or in the course outlines" has been modified to "I only study seriously what's given out in class or in the course outlines". Besides, some of the subscales were borrowed from R-SPQ-2FM as they have taken the local learner cultural issues into consideration [23]. The items which have been selected from R-SPQ-2FM such as "I want top grades in all of my courses so that I will be able to select from among the best jobs available", "When I do well in my studies, it is because I am good at it", "I reflect on what I learn and relate it to real-life experience" and etc. were inserted into the questionnaire.

Subsequently, researchers used all items in adapted SPQ to test its reliability in the context of this study. The Cronbach's alpha for surface, deep and achieving approach are shown in Table 1. According to DeVellis [24], ideally, the Cronbach's alpha coefficient of a scale should be above 0.7 . In this study, achieving approach was the only scale fulfilled this requirement, surface approach and deep approach both showed the alpha values lower than 0.7. Pallant [25] has added to the discussion of this issue "Cronbach's alpha values are, however, quite sensitive to the number of items in the scale. With short scales (e.g. scales with fewer than ten items), it is common to find quite low Cronbach values (e.g. 0.5)". As a solution to those scales which have less than ten items, Briggs and Cheek (1996, as cited in Pallant [25]) suggested reporting the mean inter-item correlation and the recommended range was between 0.2-0.4.

Table 1. Cronbach's alpha for $S A L$

\begin{tabular}{lll}
\hline Concept & Items & Alpha value \\
\hline SAL & & \\
Surface approach & 8 & 0.61 \\
Deep approach & 9 & 0.66 \\
Achieving approach & 10 & 0.72 \\
\hline
\end{tabular}

After examined the inter-item correlation, researchers found that the deep approach has fulfilled the requirement (range between $0.249-0.455$ ) but not for surface approach. They are two items in surface approach that violated this principle, namely item 9 "I can pass most of the examinations 
by remembering the main parts rather than trying to understand them." (0.197) and item 21 "I find it best to accept the fact and description of my lecturers" (-0.58). Since these two items are categorized in LM and LS respectively, therefore researchers deleted them from surface approach that increased the alpha value to 0.68. Besides, the range of inter-item correlation has improved to $0.345-0.509$.

\section{Findings}

\subsection{What are the Approaches to Learning Adopted by the Students at Private University College}

To address the first research question of this study, namely identify the learning approaches of the students, the data collected was analyzed using descriptive statistics. Findings in Table 2 indicated the learning approach most preferred by students was "deep approach" $(M=2.74)$, followed by "achieving approach" $(M=2.72)$ and "surface approach" $(M=2.65)$.

Table 2. Distribution of students approaches to learning

\begin{tabular}{llll}
\hline \multirow{2}{*}{ Descriptive Statistics } & \multicolumn{2}{l}{ Variables } & \\
\cline { 2 - 4 } & SA & DA & AA \\
\hline Mean & 2.65 & 2.74 & 2.72 \\
Standard deviation & 0.49 & 0.36 & 0.38 \\
\hline
\end{tabular}

Note: valid $\mathrm{n}=184 ; \mathrm{SA}=$ Surface Approach; DA = Deep Approach; AA = Achieving Approach.

\subsection{What are the Approaches to Learning Adopted by the Students at Private University College Based on Learning Motive (LM) and Learning Strategy (LS)}

Table 3 highlighted the preferred scores regarding LM and LS in bold. The finding indicated that "deep motive" and "achieving strategy" is the most preferred learning approach among students. The result is in line with finding of SAL using traditional way where "deep approach" is the most popular learning approach (refer to Table 2). According to Leung et al [26] (p191), students who preferred "deep motive and achieving strategy" are "typical hardworking students as they are interested in learning and intrinsically motivated to revise on a regular basis. Students employing the diligent approach do not need additional support from teachers or the teaching environment."

Table 3. Mean scores of Learning Motives (LM) and Learning Strategies (LS) of University students

\begin{tabular}{llllll}
\hline \multicolumn{2}{l}{ Learning } & Motives (LM) & \multicolumn{3}{c}{ Learning } \\
\hline Surface & Deep & Achieving & Surface & Deep & Achieving \\
motive & motive & motive & strategy & strategy & strategy \\
2.58 & 2.74 & 2.70 & 2.71 & 2.73 & 2.75 \\
\hline
\end{tabular}

A further investigation on the correlation between LM and LS was carried out in order to garner more information and better understanding of their relationship. Table 4 shows that they were significant positive correlations between LM and LS. This study reconfirmed the traditional learning phenomena among students; for instance, SM was related to SS (0.519 at a significance level of 0.0001), DM was related to DS (0.569 at a significance level of 0.0001$)$, and AM was related to AS (0.513 at a significance level of 0.0001$)$.

Table 4. Pearson Correlation of Learning Approaches of Students.

\begin{tabular}{lllll}
\hline & & SM & DM & AM \\
\hline SS & CC & $0.519^{\mathrm{a}}$ & -0.090 & 0.079 \\
& Sig. & 0.000 & 0.214 & 0.281 \\
\multirow{2}{*}{ DS } & CC & -0.069 & $0.569^{\mathrm{a}}$ & $0.430^{\mathrm{a}}$ \\
& Sig. & 0.346 & 0.000 & 0.000 \\
\multirow{2}{*}{ AS } & CC & -0.065 & $0.582^{\mathrm{a}}$ & $0.513^{\mathrm{a}}$ \\
& Sig. & 0.374 & 0.000 & 0.000 \\
\hline
\end{tabular}

Note: $\mathrm{SM}=$ surface motive; $\mathrm{DM}=$ deep motive; $\mathrm{AM}=$ achieving motive; $\mathrm{SS}=$ surface strategy; $\mathrm{DS}=$ deep strategy; $\mathrm{AS}=$ achieving strategy.

${ }^{\text {a }}$ Correlation is significant at 0.001 level (2-tailed)

Besides, positive relationship was also found between AM-DS and DM-AS (0.430 and 0.582 at significant levels of 0.0001 respectively). These results indicated that most students did apply DM together with AS and AM with DS in their learning processes. This result confirmed that the deep approach and "achieving strategy deep motive" are two most popular SALs among the students.

\subsection{Does a Discipline have an Impact on the Approaches to Learning Employed by Students at Private University College}

Table 5 showed the differences between mean scores of SAL for two groups of students, namely applied science and social science students. Apparently, the mean scores for all approaches to learning for social science students were higher than science students.

Table 5. Distribution of student approaches to learning between science and social science students.

\begin{tabular}{|c|c|c|c|}
\hline Variables & $\begin{array}{l}\text { Descriptive } \\
\text { Statistics }\end{array}$ & Science & Social Science \\
\hline \multirow[t]{2}{*}{$\begin{array}{l}\text { Surface } \\
\text { approach }\end{array}$} & Mean & 2.50 & 2.74 \\
\hline & $\begin{array}{l}\text { Standard } \\
\text { deviation }\end{array}$ & 0.52 & 0.45 \\
\hline \multirow[t]{2}{*}{ Deep approach } & Mean & 2.70 & 2.76 \\
\hline & $\begin{array}{l}\text { Standard } \\
\text { deviation }\end{array}$ & 0.38 & 0.35 \\
\hline \multirow[t]{2}{*}{$\begin{array}{l}\text { Achieving } \\
\text { approach }\end{array}$} & Mean & 2.61 & 2.80 \\
\hline & $\begin{array}{l}\text { Standard } \\
\text { deviation }\end{array}$ & 0.39 & 0.35 \\
\hline
\end{tabular}

An independent-samples t-test (Table 6) was conducted to compare the mean of these mean scores for science and social science students. 
Table 6. Independent sample t-test analysis for the SAL with disciplines.

\begin{tabular}{|c|c|c|c|c|c|c|c|c|c|c|}
\hline & & & & \multicolumn{7}{|c|}{ t-test for Equality of Means } \\
\hline & & \multicolumn{3}{|c|}{$\begin{array}{l}\text { Levene's Test for Equality } \\
\text { of Variances }\end{array}$} & \multirow[b]{2}{*}{ df } & \multirow[b]{2}{*}{$\begin{array}{l}\text { Sig. } \\
\text { (2-tailed) }\end{array}$} & \multirow[b]{2}{*}{$\begin{array}{l}\text { Mean } \\
\text { Difference }\end{array}$} & \multirow[b]{2}{*}{$\begin{array}{l}\text { Std. Error } \\
\text { Difference }\end{array}$} & \multicolumn{2}{|c|}{$\begin{array}{l}95 \% \text { Confidence } \\
\text { Interval of the } \\
\text { Difference }\end{array}$} \\
\hline & & $\mathbf{F}$ & Sig. & $\mathbf{t}$ & & & & & Lower & Upper \\
\hline \multirow[t]{2}{*}{ SA } & Equal variances assumed & 2.13 & .15 & 3.41 & 189 & .001 & .24 & .07 & .10 & .38 \\
\hline & Equal variances not assumed & & & 3.31 & 145.87 & .001 & .24 & .07 & .10 & .38 \\
\hline \multirow[t]{2}{*}{ DA } & Equal variances assumed & .39 & .53 & 1.20 & 189 & .231 & .06 & .05 & -.04 & .17 \\
\hline & Equal variances not assumed & & & 1.18 & 152.03 & .241 & .06 & .05 & -.04 & .17 \\
\hline \multirow[t]{2}{*}{ AA } & Equal variances assumed & .07 & .79 & 3.52 & 185 & .001 & .19 & .06 & .08 & .30 \\
\hline & Equal variances not assumed & & & 3.45 & 151.90 & .001 & .19 & .06 & .08 & .30 \\
\hline
\end{tabular}

Note: $\mathrm{n}=193 ; \mathrm{SA}=$ Surface Approach; DA = Deep Approach; AA = Achieving Approach.

There was a significant difference in the "surface approach" mean score between social science students $(M=2.74, S D$ $=.45)$ and science students $[M=2.50, S D=.52 ; t(189)=$ $3.408, p=.001]$; and "achieving approach" mean score between social science students $(M=2.80, S D=.35)$ and science students $[M=2.61, S D=.39 ; t(185)=3.516, p$ $=.001]$. Inspections of these two means for "surface approach" and "achieving approach" suggested that social science students were more incline to adopt "surface approach" and "achieving approach" compared to science students. The magnitude of the differences in the means was small for "surface approach" $\left(\eta^{2}=.057\right)$ and moderate for "achieving approach" $\left(\eta^{2}=.061\right)$.

\section{Discussion and Conclusion}

The results of the current study on SAL revealed that most university students preferred "deep approach" to "achieving approach" and "surface approach". This finding is deviated from the previous studies who argued that Malaysian students are surface learner [15, 18, 27, 28]. As Biggs et al. [22] have emphasized that learning approaches are the outcome of both individual characteristics and the teaching context, this result should be read in accordance with the nature of relationship between teaching context, students, and task.

There are several reasons that may cause students to adopt DA compared to other two approaches. Factors such as teaching practices with imagination and enthusiasm, prompt feedback to student work, and the issues of teacher's fairness will encourage students to employ DA [29]. Course design with contents, delivery, activities, and assessments which emphasize group work, creativity, self-learning and library research will also stimulate deep learning. Besides, when students perceive the new learning environment as positive in terms of the clarity of its goals, the usefulness of the textbook and the workload, they will be encouraged to adopt deep learning approach.

A further study on LM and LS revealed that the most popular combination of LM and LS is "DM-AS". A more accurate and specific term about the learning approach applied by the respondents in this study is "hardworking approach"
[26], whereby these students are characterized as those who are interested in learning and willing to put effort to score higher marks in their study. They are independent, internally motivated and can strive to improve themselves even without the support from teachers or environment. The suggested teaching methods to cater to this group of learners are methods that can enhance their meta- cognitive learning strategies.

This study also revealed that social science students scored higher on the surface and achieving approach compared with science students. There was no significant difference between science and social science students on deep approach to learning. However, due to the difficulties in categorizing students as pure science, applied science, pure arts and applied arts category because of the nature of courses taken by these students, it is therefore not wise to over-generalize the findings of this study. Students from other disciplines need to be examined in order to find out the relationship between SAL and disciplines. Hence, it is suggested future research can be carried out to examine the pattern of SAL.

\section{Implications and Recommendations}

This study has several implications for enhancing the learning quality of private university college students. Since the self-report questionnaire has shown that students in this study indicated a high tendency to adopt the DA, the issue here is to "what extent" and "how well" the DA was adopted. Biggs and Moore [8] mentioned that the "... approaches reflect students' predilections, not necessarily the process actually adopted. Second, approaches refer to the way the task is handled, not how well". Therefore, the actual ability of students in mastering the skills of DA needs to be ensured.

This study has also found that students have higher preference in adopting the "DM-AS" approach. However, just being aware of the knowledge (DM-AS) is insufficient, as students have to know how to put it (DM-AS) into practice. Without putting the "DM-AS" into actual practice, it would not result in any significant direct effect on educational outcomes (e.g. Academic Achievement). Hence, students should be equipped with meta-cognitive skills in order to utilize their recognition with the "DM-AS". According to 
Chalmers and Fuller [30], the term "meta-cognition" refers to two aspects of thinking: awareness about cognition and control of cognition. In this study, ostensibly, students have awareness about cognition, but what they may lack is the control or regulation of cognition.

Based on the discussion presented above, researchers recommended the following suggestions for educators and students. Firstly, lecturers should reflect on the use of various teaching methods that are more student-focused rather than teacher-focused teaching approaches. As a good lecturer, one should not just do well in teaching, but must be able to be effective in pedagogical skills, classroom management, and understand the characteristics of the learner. Most importantly, a good lecturer should always be prepared to listen to the voice of students. Secondly, lecturers are also recommended to increase the multi-way teaching approach through group discussions, practical training, project-based or problem-based learning, as well as hands-on activities in order to promote students' study interests [11]. Thirdly, students hold the master key to choose the way they approach the course. A smart student perceives his/her learning situations, including the lecturer's teaching approach from a positive perspective; conversely, a poor performing student perceives everything from a negative view point. In other words, a smart student will always find ways to improve his/her learning qualities instead of blaming external factors. Lastly, a student should look for a great volume of relevant knowledge; operate at a high, or abstract level of conceptualization. He/she should apply meta-cognitive strategies in the study; enjoys the learning process and is prepared to invest time and effort in his/her studies [8]. Of course, meta-cognition is a thinking process that can be learned and trained [30].

\section{Limitation}

There are several limitations in this study. This study is purely conducted to reveal the student approaches to learning (SAL) among university students. Other external factors, such as social environment, economic situation, learning environment, personality of students and educators, and previous experience which may function as predictors to the adopted learning approaches have not been studied. Further study of these factors is recommended in order to obtain a better understanding about the predictors of SAL among the students in Malaysia.

Besides, to what extent the adopted learning approaches will affect learning outcomes, such as academic achievement, learning engagement and students' ability has not been examined. Future research can be conducted to investigate the relationship between the adopted learning approaches and learning outcomes.

\section{Acknowledgements}

The writers would like to thank Professor John Biggs for kindly allowing the study process questionnaire to be adapted and used for this study.

\section{References}

[1] Y. C. Kek, I. G. N. Darmawan, and Y. S. Chen, "Family, learning environments, learning approaches, and student outcomes in a Malaysian private university," International Education Journal, vol. 8(2), pp. 318-336, 2007.

[2] C. M. Rodriguez, "The impact of academic self-concept, expectations and the choice of learning strategy on academic achievement: the case of business students," Higher Education Research \& Development, vol. 28(5), pp. 523-539, 2009.

[3] M. Rollnick, B. Davidowitz, M. Keane, A. Bapoo, and L. Magadla, "Students' learning-approach profiles in relation to their university experience and success," Teaching in Higher Education, vol. 13(1), pp. 29-42, 2008.

[4] A. B. Swanberg and Ø. L. Martinsen, "Personality, approaches to learning and achievement," Educational Psychology, vol. 30(1), pp. 75-88, 2010.

[5] F. Marton and R. Säljö, "On qualitative differences in learning I. Outcome and process," British Journal of Educational Psychology, vol. 46, pp. 4-11, 1976.

[6] B. Dasari, "Hong Kong students' approaches to learning: Cross-cultural comparisons," US-China Education Review, vol 6(12), pp. 46-58, 2009.

[7] J. B. Biggs, Student approaches to learning and studying. Hawthorn, Vic: Australia Council for Edu. Research, 1987.

[8] J. B. Biggs and P. J. Moore, The process of learning $\left(3^{\text {rd }}\right.$ edition). Australia: Prentice Hall, 1993.

[9] N. J. Entwistle, "Approaches to learning and perceptions of the learning environment: Introduction to the special issue," Higher Education, vol. 22, pp. 201-204, 1991.

[10] Hanin Naziha Hasnor, Zaiton Ahmad and Norshidah Nordin, "The relationship between learning approaches and academic achievement among INTEC students, UiTM Shah Alam," Procedia - Social and Behavioral Sciences, vol. 90, pp. 178 186, 2013.

[11] M. Y. Leung, Y. Wang, and K. K. David Chan, "Structural Surface-Achieving model in the teaching and learning process for construction engineering students," Journal of professional issues in engineering education and practice, pp. 327-339, 2007.

[12] M. Tani, "Quiet, but only in class: reviewing the in-class participation of Asian students," retrieved from Higher Education Research and Development Society of Australasia Incorporated (HERDSA) website: http://conference.herdsa.org.au/2005/pdf/non_refereed/030.pd f. 2005 .

[13] C. Ziguras, "Educational technology in transnational higher education in South East Asia: The cultural politics of flexible learning," Educational Technology \& Society, vol. 4 (4), retrieved from http://www.ifets.info/journals/4_4/ziguras.html. 2001.

[14] D. Kember, "Misconceptions about the learning approaches, motivation and study practices of Asian students," Higher Education, vol. 40(1), pp. 99-121, doi: 10.1023/A:1004036826490. 2000. 
[15] L. Y. Fung, "A study on the learning approaches of Malaysian students in relation to English language acquisition," American Journal of Scientific Research, vol. 9, pp. 5-11, 2010.

[16] S. M. Thang, "Investigating autonomy of Malaysian ESL learners: a comparison between public and private universities," 3L; Language,Linguistics and Literature,The Southeast Asian Journal of English Language Studies, vol. 15, pp. 97-124, 2009.

[17] S. C. Pauline Goh, "Perceptions of learning environments, learning approaches, and learning outcomes a study of private higher education students in Malaysia from twinning programmes," Doctoral dissertation, University of Adelaide, Australia, retrieved from http://digital.library.adelaide.edu.au/dspace/bitstream/2440/37 753/2/01 front.pdf. 2005.

[18] P. Ling, G. Arger, I. Filonenko, H. Chua, and C. Yin, "Approaches to study: A comparison of Malaysian and Australian students, in Higher education in a changing world," Proceedings of the 28th HERDSA Annual Conference, pp. 276-286, retrieved from HERDSA website: http://www.herdsa.org.au/wp-content/uploads/conference/200 5/papers/ling_p.pdf. 2005.

[19] S. M. Thang, "Comparing approaches to studying of Malaysian distance learners and on-campus learners: implication to distance education," Turkish Online Journal of Distance Education-TOJDE, vol. 6(2), pp. 70-86, 2005.

[20] Zahariah Mohd Zain, Irfah Najihah Basir Malan, Fauziah Noordin and Zaini Abdullah, "Assessing student approaches to learning: A case of business students at the Faculty of Business Management, Universiti Teknologi MARA," Procedia - Social and Behavioral Sciences, vol. 90, pp. $904-913,2013$.

[21] H. C. Teoh, Maria Chong Abdullah, Samsilah Roslan, and Shaffe Daud, "Assessing students approaches to learning using a matrix framework in a Malaysian public university," SpringerPlus, vol. 3(54). doi:10.1186/2193-1801-3-54, 2014.

[22] J. Biggs, D. Kember, and D. Y. P. Leung, "The revised two-factor Study Process Questionnaire: R-SPQ-2F,” British Journal of Educational Psychology, vol. 71, pp. 133-149, 2001.

[23] P. L. Tan, "Approaches to learning and learning values: An investigation of adult learner in Malaysia," Doctoral dissertation, Queensland University of Technology, Australia, retrieved from http://eprints.qut.edu.au/16295/. 2005.

[24] R. F. DeVellis, Scale development: Theory and applications $\left(2^{\text {nd }}\right.$ edn). Thousand Oaks, California: Sage, 2003.

[25] J. Pallant, SPSS survival manual: A step by step guide to data analysis using SPSS ( $4^{\text {th }}$ edn.). Australia: Allen \& Unwin, 2011.

[26] M. Y. Leung, S. T. Ng, and Y. K. Li, "Evaluating the learning approaches of construction students in Hong Kong through a matrix framework," Journal of Professional Issues in Engineering Education and Practice, vol. 130 (3), pp. 189-196, 2004.

[27] S. N. Smith, "Approaches to study of three Chinese national groups," British Journal of Educational Psychology, vol. 71, pp. 429-441, 2001.

[28] Wan Zah Wan Ali, Memahami Pembelajaran. Kuala Lumpur: Utusan Publication \& Distributors Sdn Bhd., 2000.

[29] S. C. Pauline Goh, "Teaching practices that hinder the deep approaches to learning of twinning programme students in Malaysia: A Qualitative Perspective," The Asia-Pacific Education Researcher, vol. 17(1), pp. 63-73, 2008.

[30] D. Chalmers and R. Fuller, "Teaching for learning at University". Britain: Kogan Page, 1996. 